\title{
Will the United States Republic Become a Dictatorship?
}

\author{
Valentine J. Belfiglio, Ph.D.* \\ Texas Woman's University USA
}

*Corresponding Author: Valentine J. Belfiglio, Ph.D., Texas Woman's University USA

\begin{abstract}
Thesis Statement: Democratic governments transform into dictatorships when their cultures replace virtue and social capital with vice and selfishness. Methodology: Historiography and conceptual analysis of the writings of ancient and modern intellectuals and historians. Results: Vice and selfishness initiates wars, promoted by the military-industrial complex, and the unequal distribution of wealth and social status. Exploitation of the working and lower classes of citizens and non-citizens causes frustration and anger leading to political, economic and social chaos. To deal with the chaos upper class and upper-middle class citizens, unmindful of the root cause of the disorder, demand law and order. A dictator emerges who promises peace, justice and order. Conclusion and Implications: The U.S. republic must preserve virtue and social capital in order for democracy to survive.
\end{abstract}

Key terms: virtue, vice, class, democracy, dictatorship, social capital.

\section{INTRODUCTION}

During the early $6^{\text {th }}$ century B.C. two remarkable progressive political events occurred. In 509 B.C., prominent members of the Roman elite, led by Lucius Junius Brutus and Publius ValeriusPublicola, overthrew the tyrannical rule of Tarquinius Superbus, and established a Republic. ${ }^{1}$ One year later Cleisthenes, overthrew the totalitarian rule of Pisistratus and established democracy for the city of Athens. ${ }^{2}$ These events took place when dictatorships or oligarchies were the norm throughout the world. This paper defines Athenian democracy and Roman republican democracy as: "A system of government in which ultimate political authority was vested in adult, male citizens." Lao Tzu wrote: "Any man can be broken by a strength outside which is stronger than himself or a weakness within himself which he does not understand." ${ }^{3}$ The same is true of political regimes. ${ }^{4}$ Athenian democracy lasted until the army of Phillip II of Macedonia conquered the city in 338 B.C. The Roman republic transformed into the dictatorship of an emperor in 27 B.C. because of internal changes caused by fear. $^{5}$

The American founders seemed impressed by the Roman republic. Alexander Hamilton wrote: “. . . the Roman republic attained to the utmost height of human greatness." However, Thomas Jefferson was mindful of the transformation of the Roman republic to a dictatorship. In a letter to John Adams he inquired: ". . . what was the government which the virtues of Cicero were so zealous to restore, and the ambition of Caesar to Subvert?" Adams replied: . . . without Virtue there can be no political liberty ... "riches and luxury inevitably lead to effeminacy intoxication extravagance vice and

\footnotetext{
${ }^{1}$ Cassius Dio, Roman History, trans. Earnest Cary (Cambridge, MA.: Harvard University Press 1917), 3.13.1-4; 4.14; Livy, History of Rome, 1.60 .

${ }^{2}$ Christian Habicht, Athens from Alexander to Antony (Cambridge: Harvard University Press, 1997), 42.

${ }^{3}$ Lao Tzu, Tao Te Ching, trans. Bryce Derek (New York: Samuel Weiser, 1991) 2.55.1-4.

${ }_{5}^{4}$ Lao Tzu, Tao Te Ching, 2.58.1-3.

${ }^{5}$ Gaius Suetonius Tranquillus, The Twelve Caesars, translated by Robert Graves "Augustus," (New York: Penguin Books, 1989), 58.1-3.

${ }^{6}$ Gary Wills, The Federalist Papers, Federalist No. 34: Hamilton to the People of the State of New York, January 5, 1788 (New York: Bantam Books, 1982), 159-160.

${ }^{7}$ Saul K. Padover, A Jefferson Profile as Revealed in his letters. Thomas Jefferson to John Adams, December 10, 1819, Monticello (New York: The John Day Company, 1956), 309.
} 
folly." ${ }^{8}$ For the purposes of this paper "virtue", related to Greek Stoicism, means "patriotism and public spirit, a heroic willingness to set the common good above one's interests, typified by the ideals chronicled by Livy and Plutarch." "Vice", related to Greek hedonism, means "civic indifference, selfish ambition, sensual pleasure and pursuit of wealth and power solely for one's benefit, typified by tyrants chronicled by Suetonius and Tacitus. ${ }^{10}$ " Harold C. King identified the three key Roman virtues emphasized during Res Publica, as virtu, gravitas and pietas. Virtu was courage in war and integrity in peace. Gravitas was seriousness and dignity in conduct. Pietas was readiness to perform duty toward the family, the gods and the state. This triad produced a Roman ideal of a serious, steadfast, adaptable and purposeful man who subordinated himself to public responsibility. ${ }^{11}$ In 1776 The American founders expressed similar virtues in the U.S. Declaration of Independence. They wrote: “. . . with a firm Reliance on the Protection of divine Providence, we mutually pledge to each other our Lives, our Fortunes and our sacred Honor." 12

Philosophers of every age have recognized a connection between virtue and a viable democratic republic. The writings of Aristotle, Polybius, Cicero and Augustine stressed an ideal that placed virtue and law above the rule of men. For example, Herbert Spencer (1820-1903), an English philosopher wrote: "The Republican form of Government is the highest form of government; but because of this it requires the highest type of human nature-nowhere at present existing." ${ }^{13}$ When a society loses virtue unethical behavior, iniquity, viciousness and atrocities and even revolution may follow.

\section{SCOPE AND METHOD}

The Roman republic transformed into a dictatorship because of an erosion of virtue and a proliferation of vice. Historiography and conceptual analysis of the writings of ancient and modern scholars, inscriptions, pictorial sources, coins, ad archaeological discoveries. Lack of virtue, pernicious social unrest based on political, social and economic inequalities, frequent military conflicts and civil war undermined public confidence in the Roman republic. The Roman republic transformed into a dictatorship because of an erosion of virtue and a proliferation of vice. The U.S. Republic faces many of these ills and can thrive and progress by avoiding or overcoming the mistakes of the Romans.

\subsection{The Roman Republic}

The Roman republic was not a democracy in the modern meaning of the term. The Patrician class dominated the political system through the Roman Senate but made increasing concessions to the lower-class plebeians. The patricians formed the highest social stratum in the Republic. The Plebeians were the general populace of Rome. The 300-member Senate, led by two consuls, prepared proposals to bring before the people, passed decrees, dealt with emergencies, controlled finances and building contracts, appointed magistrates to provinces, directed foreign relations and supervised state religion. ${ }^{14}$ There were four assemblies designed to check and balance the powers of the consuls and senate. The most important of these assemblies were the comitia centuriata and Concilium Plebes. The 193-member comitia centuriata had the power to declare war and elect the highest-ranking Roman magistrates including the two consuls, six praetors and the censors. This body wrote early guidelines for the Republic known as the Twelve Tables (450 B.C.). ${ }^{15}$ The 35 -member Concilium plebes could pass laws and elected 10 tribunes each of which had veto power over the actions of the Consuls, magistrates, Senate or other assemblies. Six praetors served as a court of last resort in all judicial matters. ${ }^{16}$ Roman client states offered an early version of federalism. Client states exercised

\footnotetext{
${ }^{8}$ Lester J. Cappon, The Adams-Jefferson Letters, December 21, 1819, Montezillo (Chapel Hill: The University of North Carolina Press, 1988), 550-551.

${ }^{9}$ Plutarch, Plutarch's Lives, "Pericles," "Gaius Marius," "Cicero," I.1-46, 6.1.-49.

${ }^{10}$ Suetonius, The Twelve Caesars, "Gaius Caligula," "Nero," 4.1-60, 6.1-57.

${ }^{11}$ Harold C. King, A History of Civilization (New York: Charles Scribner's Sons, 1969), 111.

${ }^{12}$ U.S., Declaration of Independence, Philadelphia, 1776 (Washington, D.C.: Cato Institute, 2004), 14

${ }^{13}$ Herbert Spencer, Essays: Scientific, Political, and Speculative Vol. III "The Americans" (London: Williams and Norgate, 1891), 478-479.

${ }^{14}$ Polybius, The Histories of Polybius, trans. W.R. Paton (William Heinemann, 1922) 6.11-17.

${ }^{15}$ Titus Livius (Livy), History of Rome, trans. B.O. Foster, E.T. Sage, and A.C. Schlesinger (Cambridge, Mass:

Harvard University Press, 1919-1957), 3.34.

${ }^{16}$ Livy, History of Rome, 3.55.
} 
internal autonomy but were sometimes required to pay taxes to Rome, furnish young men for the Roman auxiliary army and yield to Roman authority in all foreign policy matters. ${ }^{17}$

\subsection{From Republic to Dictatorship}

Many theories exist on why the Roman republic transformed into a dictatorship. What is certain is that this transformation occurred and legitimized through institutions designed to protect republican values. Sallust and Livy, two Roman historians, pointed to the underlying consequences of Roman conquests. Sallust wrote: "when glory, dominion, and power followed in their train, virtue began to lose its luster." 18 Livy Added: "the state has grown so large . . . that it struggles under the incubus of its own great size." 19 The Roman political system featured an interlocking directorate between the political and military systems. Polybius wrote that: "no one is permitted to hold any political office until he has completed 10 years of military service." 20 Therefore, every public official in the executive, legislative and judicial branches of government were on active duty or veterans. Ambitious men and the Roman state could only advance through military conquests and valor.

Roman society was stratified by class. Citizenship was very important to the system. Patricians, the noble class, formed the highest social stratum in the Republic. Equites (knights) served as the middle class, situated between the patricians and the plebeians (general citizenry of Rome). Freedmen who were non-citizens could engage in social and economic enterprises but could not vote or hold public office were next in the social stratum followed by slaves. ${ }^{21}$

\subsection{The Effects of Continual Warfare}

Warfare is an expensive undertaking. Wealthy patricians who comprised the majority of the higherranking military officers such as tribunes and consuls could afford to allow a trusted subordinate to manage his rural farms and ranches, or commercial enterprises and apartment complexes. Rural plebeians who comprised the majority of the enlisted ranks, owned small farms or small shops, without trusted subordinates, which often had to be abandoned during military service. ${ }^{22}$

Three factors induced continual military expansionism. The first reason was vengeance for past defeats in war. The Gallic invasion of Rome in 390 B.C., The Samnite victory at Caudine Forks in 321 B.C., and The Carthaginian victory at Cannae in 216 B.C. gave ambitious Roman generals excuses to wage wars primarily motivated by personal ambitions. ${ }^{23}$ The second factor for continual military expansionism was success in war. Total military victories over Rome's major military, political and economic competitors brought wealth and glory to Roman generals and the Roman republic. Examples are the destruction of Carthage in 146 B.C, ${ }^{24}$ the incorporation of Greece as a province into the Roman state that year ${ }^{25}$ and the incorporation of Egypt in 30 B.C. ${ }^{26}$ the third reason for Roman military expansionism was the existence of disunited states comprised of independent tribes or a loose confederation of tribes in Gaul, Spain, Africa and elsewhere. Tribal armies were no match for the disciplined, trained, tactical agility and uniformly armed legions. The army was legally and bureaucratically organized, regulated, recruited, commanded and supplied. ${ }^{27}$

Why were the Romans more militarily advanced than most if its neighbors? There are three plausible reasons. If ancients' historians are correct the Romans were descendants of an advanced civilization

\footnotetext{
${ }^{17}$ R.G. Collingwood, Roman Britain (New York: Barnes \& Noble, 1994), 1-16.

${ }_{18}$ GaiusSallust, The War with Catiline, trans. J.C. Rolfe(Cambridge, MA: Harvard University Press, 2005), XII.1-3.

${ }^{19}$ Livy, History of Rome, Preface.3.

${ }^{20}$ Polybius, The Histories, trans. W.R. Paton (London: William Heinemann, 1926), VI.19.

${ }^{21}$ Livy, History of Rome, 1.43.; Polybius, The Histories, 6.11-18.

${ }^{22}$ Plutarch, "Tiberius and Gaius Gracchus," Plutarch's Lives, trans. Bernadotte Perrin (London: William Heinemann, 1921), 9.

${ }^{23}$ Livy, History of Rome, 5.37-38, 5.39-42; 9.26.2; 22.43.10-49; Polybius, The Histories, 2.18.1-3; 3.110-117; Plutarch, "Fabius Maximus," Plutarch's Lives, 15-16; Appian, The Hannibalic War, trans. Horace White (Cambridge, MA: Harvard University Press, 1912), IV.19-26.

${ }^{24}$ Appian, The Punic Wars, 8.19.127-132.

${ }^{25}$ Livy, History of Rome, epitome 52.

${ }^{26}$ Plutarch, "Antony," Plutarch's Lives, 61-68.3; Cassius Dio, Roman History, 50:12-35.

${ }^{27}$ Polybius, The Histories, 6.19-40.
} 
known as Troy in western Turkey. After the Mycenean Greeks destroyed the city in 1,180, Prince Aeneas, son of king Anchises, sailed away from the city with hundreds of refugees. ${ }^{28} \mathrm{He}$ was serious wounded in battle and unable to further serve in combat. ${ }^{29}$ Aeneas arrived in Rome after several years of wandering around the Mediterranean Sea. Several ancient historians attest to this event. They include Livy, Dio and Appian. ${ }^{30}$ The second reason for the military successes of Rome was an advanced civilization to the north of Rome called Etruria. The Romans learned architecture, ritual practices and some military tactics from them. The most important reason for Roman military success came from Greek colonies in southern Italy. The Romans adopted Greek weapons, armor, military strategies and tactics to their advantage. They also adapted some of these techniques and improved upon them. The Greek phalanx gave rise to the Roman checkerboard formation, the Greek spear evolved into a javelin and the Greek round shield gave way to a rectangular shield with a boss in the center. ${ }^{31}$ Above all, the Roman legionnaire adopted the Greek stoic ideal that surrender was never an option. Polybius wrote: "They must either conquer or die on the field." ${ }^{32}$ Dupont, a noted historian, assessed the character of the typical Roman legionnaire: "His inhumanity was fashioned of steel. . . An enemy could do nothing to them, except kill them". ${ }^{33}$

Polybius was among many historians who expressed serious concern about the fate of the Roman Republic. He wrote: "When a state achieves supremacy and uncontested sovereignty, under the influence of long-established prosperity life will become more luxurious, and rivalry for office and other spheres of activity will become fiercer ... the spread of ostentation and extravagance, will usher in a period of general deterioration. ${ }^{34}$ Sallust attributed Roman freedom to the virtue of her citizens, and the loss of the freedom to corruption caused by luxurious living. ${ }^{35}$ Sallust attributed Roman freedom to the virtue of its citizens, and the loss of that freedom to corruption caused by luxurious living. He wrote: "As soon as riches came to be held in honor, when glory, dominion, and power followed in their train, virtue began to lose its luster ${ }^{36}$."Thus, over time egotism, materialism, hedonism, envy, selfishness and pursuit of wealth and power displaced the Roman virtues of virtu, gravitas and pietas.

The republican period of Roman history there was an era of continual warfare, insurrections, economic inequalities and political uncertainties. Examples of major wars during the Republic include: Conquest of Italy (405-265 B.C.), First Punic War (264-241 B.C.), Second Punic War (219202 B.C.), First Macedonian War (215-205 B.C.), Second Macedonian War (200-196 B.C.), War with Syria (192-188 B.C.), Third Macedonian War (172-167 B.C.), Third Punic War (149-146 B.C.), Jugurthine War (112-106 B.C.), First Mithridatic War (89-84 B.C.), Second Mithridatic War (83-81 B.C.), Third Mithridatic War (75-65 B.C.), The Gallic Wars (58-51 B.C.), The Roman Civil War (5044 B.C.), Wars of the Second Triumvirate (43-34 B.C.), and the Second Roman Civil War (33-30) B.C. ${ }^{37}$ Insurrections against Roman rule during the Republic were also common. Examples include: The Jewish uprising (66-73 B.C.) ${ }^{38}$ The Social War (91-88 B.C.) ${ }^{39}$ and three slave uprisings (135-132 B.C.), (104-100 B.C.), and (73-71 B.C.). ${ }^{40}$

\section{A Period of Political, Economic and Political Chaos}

\footnotetext{
${ }^{28}$ Homer, The Iliad, trans. Robert Fagles (New York: Penguin Books, 1991), 5.270; Barry Strauss, The Trojan War (New York: Simon \& Schuster, 2006), 177.

${ }^{29}$ Homer, The Iliad, 5.330-340.

${ }^{30}$ Livy, History of Rome, 1.1-3.; Dio, Roman History, 1. Zonaras 7.1.; Appian, Concerning the Kings, 1.1-2.

${ }^{31}$ Polybius, The Histories, 6.22-25.

${ }^{32}$ Polybius, The Histories, 6.58 .

${ }^{33}$ Florence Dupont, Daily Life in Ancient Rome (Malden, MA: Blackwell, 1997), 126, 134.

${ }^{34}$ Polybius, The Histories, 6.57.

${ }^{35}$ Sallust, The War with Cataline, 11.3, 12.1; Publius Tacitus, The Annals of Imperial Rome, trans. Michael Grant (New York: Barnes \& Noble, 1971), 14.14-65; 15.32-47.

${ }^{36}$ Sallust, The War with Cataline, 11.12.1-2.

${ }^{37}$ For a discussion of the impact of these wars and other conflicts upon Roman society consult Philip Matyszak, Chronicle of the Roman Republic (London: Thames \& Hudson, 2003).

${ }^{38}$ Flavius Josephus, The Jewish War, trans. G.A. Williamson (New York: Penguin Books, 1981), 7.1-444.

${ }^{39}$ Appian, the Civil Wars I 41-53.

${ }^{40}$ Appian The Civil Wars 1.117-120
} 
Continual wars cause death, grotesque wounds, severed limbs and mental anguish. Polybius writes that 70,000 Roman soldiers died in one battle at Cannae in 216 B.C. ${ }^{41}$ In addition, the cost of war, especially civil war, where booty could not displace the cost of war, drained the state economy. Many discharged soldiers and civilians experienced misery, poverty fear and uncertainty. Ownership of land was important to a majority of Romans since the economy was largely based on agriculture. Patricians often purchased the land of peasant farmers away at war, who could not pay their property taxes or take care for their farms. Tiberius (163-133 B.C.) and Gaius (154-121 B.C.) Gracchus, tribunes of the plebeians, were Roman brothers, who tried to enact agrarian reforms for small, independent farmers by granting plots of public land to them in colonies. Wealthy patrician Senators saw these reforms as a threat to their large agrarian plantations. They hired thugs to kill Tiberius in 133 B.C. and Gaius committed suicide in 121 B.C. The Senate repealed most of their reforms. ${ }^{42}$

Citizenship allowed political and social privileges denied to non-citizens. Citizens could vote and run for public office. They were also eligible to join the Roman army as a legionnaire. Non-citizens could not vote, hold public office or join the legions. However, they could serve as auxiliary forces and receive Roman citizenship for themselves and their families after 25 years of honorable service. From 90-82 B.C. the Italian allies of Rome struggled to secure Roman citizenship promised them by Tribune Livius Drusus in 91 B.C. but denied by the Roman Senate. Conflict raged and became known as the Social War. ${ }^{43}$ Thus, economic stagnation, slave revolts and social injustice precipitated political chaos. Many Romans experienced fear, uncertainly and doubt about their futures and the future of the Republic. They looked for a strong leader to establish peace and stability. Roman law provided for the appointment of consuls or other major official as dictator by the Senate in time of crisis. The dictator ruled for a maximum of six months and had sole control over military and domestic matters to deal with the crisis. The dictator appointed a second-in-command (magister equitum) himself. ${ }^{44}$

Lucius Cornelius Sulla was the first Roman general to abuse the power of the dictatorship. He had a distinguished military record, received the award of Grass Crown during the Social War, and held the position of Consul in 88 and 80 B.C. In 88 B.C. Sulla and his army temporarily crushed the proponents of extending Roman citizenship during the Social War led by Sulpicius Rufus and Gaius Marius. Opposition continued and Sulla again seized Rome and made himself dictator. Sulla reigned as dictator from 82-79 B.C. He then restored the authority of the Senate, permitted free elections and retired. However, Plutarch points out: "The chief danger to the republic was, as Sulla's own career had shown, the rebellious proconsul at the head of an army more loyal to himself than to Rome, and it was Sulla's total failure to check this menace that contributed most to the rapid collapse of his system." 45

The next Roman general to abuse the power of the dictator was Gaius Julius Caesar. After scoring spectacular victories in Gaul (58-51 B.C.), Consul Gnaeus Pompey ordered Caesar to give up his provinces, disband his army, and return to Rome, or else be declared a traitor. Pompey had been the leader of the Optimates, the party of the aristocrats, and Caesar was a champion of the Populares, the party of the people. There was great rivalry between the two men. Caesar feared if he obeyed Pompey's orders his political career would be over, and he might face legal charges. In 49 B.C. Caesar crossed the River Rubicon from Gaul and the great Roman Civil War (49-44 B.C.) began. ${ }^{46}$ Pompey was a skilled general with a distinguished military career, but he confronted one of the greatest military minds of antiquity. Caesar prevailed and the final battle took place at Munda, Spain in 45 B.C. ${ }^{47}$ Prior to this victory Caesar established Cleopatra as Queen of Egypt and had a son by her. The Senate appointed him dictator for life and he conquered Pontus and Libya. The stage was set for him to realize the dream, he shared with Cleopatra, of equaling the conquests of Alexander the Great.

\footnotetext{
${ }^{41}$ Polybius, the Histories 3.117.

${ }^{42}$ Dio, Roman History, 24.83-84, 25.85.

${ }^{43}$ Appian, The Civil Wars, 1.40-43.

${ }^{44}$ Livy, History of Rome, 2.18.

${ }^{45}$ Plutarch, "Sulla," Plutarch's Lives, 1.

${ }^{46}$ Plutarch, "Pompey," Plutarch's Lives, 56; Plutarch, "Caesar," 29-35.

${ }^{47}$ For the Roman Civil War of 49-44 B.C., consult, Gaius Julius Caesar, The Civil War, trans. Jane F. Gardner (New York: Penguin Books, 1967).
} 
He would conquer Parthia, Scythia and Germany. ${ }^{48}$ Caesar's assassination by a group of Senators on March 15, 44 B.C. ended this dream. ${ }^{49}$ Nevertheless, the stage was not set for a cleverer man to end the Republic and initiate a dictatorship in the form of emperor.

In the struggle for power that ensued after Caesar's death, including the Wars of the Second Triumvirate (43-34 B.C.) and War between Gaius Octavian and Marc Antony (33-30 B.C.) Octavian prevailed and the Roman Senate conferred upon him the name of Augustus Caesar. Octavian desired absolute authority over the Roman state but would not make the mistakes of Sulla and Caesar. He restored the outward façade of the Republic, with governmental power vested in the Senate, executive magistrates and legislative assemblies. He then gained support of the military with bonuses and the populace with inexpensive food and games. Octavian promised the war-weary people of Rome a Pax Romana (Roman Peace). Through promises. Rewards, and subtle threats he induced the Roman Senate to vote to grant Octavian supreme military command, and the powers of tribune and censor through two laws passed in 23 B.C. These laws were in imperium maius and tribuniciapotestas ${ }^{50}$. Dio wrote in 21 B.C. "It was impossible for a democratic government to be maintained." ${ }^{51}$ Octavian rejected the title of dictator, and instead called himself Princeps Civitatis (First Citizen). Then by executive decrees, and the use of implied and inherent powers he gradually absorbed the functions of the Senate, the officials, and even the law. Augustus appointed family and trusted friends to powerful governmental positions. On A.D. 14 Tacitus, Rome's greatest historian wrote:

The country has been transformed, and there was nothing left of the fine old Roman character. Political equality was a thing of the past; all eyes watched for imperial commands" ${ }^{\text {"F }}$ From 23 B.C. until its collapse in A.D. 476 authoritarian emperors ruled Rome. Nearly two thousand years later the German Reichstag voted to grant Adolf Hitler similar dictatorial powers over the German state through the Enabling Act. ${ }^{53}$ Octavian and Hitler dramatically changed the Roman Republic and Hitler made similar changes in the Weimar Republic. They initiated systems of rule that, although based on the support of all republican customs, subjugated these republics to their own, personal authority. Octavian become known as Caesar Augustus, and Hitler as Fuhrer. The two men assumed absolute control of the political systems they governed. Could this same process happen to the United States Republic?

\section{LESSONS FOR THE UNITED STATES REPUBLIC}

Although two thousand years separate them the Roman and United States republics have common institutional features. These features include: the rule of law, federalism. Checks and balances and elected representation. Rome had two executive leaders known as consuls. When there was a dispute between the two, force of personality (Julius Caesar and Marcus Bibulus) (59-58 B.C.) or the will of the Senate. America has one president and one vice president. In modern times presidents assign vice presidents important executive responsibilities; thereby more closely reflecting the Roman model. The Roman and United States republics functioned with two political groups with opposing interests and objectives.$^{54}$ The Roman legislative system was quadricameral but only two assembles acted on most legislation: The Senate and Tribal Assembly. The Unite States legislature is bicameral. A Tribune of the plebeians could veto enactment of Roman laws; The President of the United States can veto enactment of American laws. Six praetors exercised final judicial authority in Rome which is the quorum necessary for the U.S. Supreme Court to issue judicial decisions. The democracy practiced by the Romans resembles the democracy practiced in the United States prior to the American Civil War.

\footnotetext{
${ }^{48}$ Plutarch, “Caesar,” Plutarch's Lives,49, 55, 57-58

49 Plutarch, "Caesar," 66,67.

${ }^{50}$ Dio, Roman History, 53.11-17.

${ }^{51}$ Dio, Roman History, 54.6.2.

${ }^{52}$ Cornelius Tacitus, The Annals of Imperial Rome, trans. Michael Grant (New York: Barnes \& Noble, 1971), 1.7.6.

${ }^{53}$ William L. Shirer, The Rise and Fall of the Third Reich (New York: Simon and Schuster, 1960), 198.

${ }^{54}$ For the American system, the Democratic and Republican parties. For the Roman system, the Optimates and Populares. The Republican Party and the Optimates favored conservatism, while the Democratic Party and Populares favored liberalism.
} 
Virtue is not a common term used in modern America. However, social capital does resonate with many. Social capital is the effective functioning of social groups through interpersonal relationships, a shared sense of identity, a shared understanding, shared norms, shared values, trust, cooperation, and reciprocity. Social capital is a measure of the value of resources, both tangible (e.g., public spaces, private property) and intangible (e.g., actors, human capital, people), and the impact that these relationships have on the resources involved in each relationship, and on larger groups. It is generally seen as a form of capital that produces public goods for a common purpose. This concept is based on the ideal of the value of a common bond for all Americans based on citizenship, humanitarianism, and equal justice and opportunity for all. ${ }^{55}$ Modern American society faces many of the same political, social and economic problems as the ancient, Roman Republic. There is a waning of civic virtue by an affluent faction of society, which focuses more on materialism, commercialism and consumerism than on civic responsibilities. Critical and conflict theorists emphasize that elites exercise political dominance to serve their own interests rather than the public good. Executives of large companies, high-ranking military leaders and career politicians are the Patricians of modern America, and social class based on wealth dominates the political spectrum. The upper class-five percent of the U.S. population, yet the overwhelming majority of business owners, corporate executives and senior governmental officials, including American presidents emerge from this class. ${ }^{56}$

There is a growing gap between the rich ad poor, and a hardening of ideological differences between the Democratic and Republican parties often leading to stagnation in the U.S. Congress. Some career politicians practice fraud and corruption. Antifa and Black Lives Matter commit crimes against people and property. Black Lives Matter formed in 2013 in response to the acquittal of Travon Martin's murderer. The Corona Virus pandemic and violent protests in major American cities caused many Americans to experience anxiety, fear and cynicism. As a result, civic engagement, social connectiveness and social capital declined, and Identity politics replaced trust, cooperation and reciprocity. ${ }^{57}$ Black Lives Matter is a response to past injustices committed against African Americans. African Americans suffered slavery until the American Civil War (1861-1865). There followed decades of discrimination against these American citizens. Several decisions by the U.S. Supreme Court and Acts of Congress sought to provide equal justice for all citizens. The Civil Rights legislation of 1964 and 1965 were especially effective. The policy of Affirmative Action evolved from these Congressional Acts. The policy encouraged government contractors and private institutions to recruit underrepresented racial minorities. ${ }^{58}$ The U.S. Supreme Court upheld bilingual education in 1974 to further advance the rights of minority populations. ${ }^{59}$ This Supreme Court decision and Congressional laws were just, but unwittingly contributed to identity politics and the erosion of social capital.

The concept of diversity means that people are different in their ethnicity, race and gender, and although this is true overemphasizing diversity delimits what Americans have in common and detracts from the common good and social capital. A society which proclaims black lives matter while acknowledging that it is politically incorrect to say that all lives matter sets the stage for racial divisiveness. Some members of the Black Lives Matter organization seek to avenge the death of African Americans by rogue police officers by harassing other police officers ${ }^{60}$. Antifa is a neoMarxist organization whose members believe that police officers are the enforcement arm of an outdated nation state. System. ${ }^{61}$ Lao-tzu wrote: "Vengeance is like a water vessel with a hole in it. It carries nothing but the promise of emptiness. Evil cannot be removed from the world. It can only be resisted within oneself." ${ }^{\circ 2}$ Some members of Antifa advocate the overthrow of the U.S. Government through force and violence. A majority of its adherents are Marxists or revolutionary socialists. Antifa subscribes to a multifaceted radical ideology, with violent demonstrations challenging the established political, social, and economic order. The main unifying themes of antifa are common opposition to

\footnotetext{
${ }^{55}$ Leonard Broom, Sociology (Belmont: CA.: Wadsworth, 1990), 144-149.

${ }^{56}$ John J. Macionis, Sociology (New York: Pearson, 2017), 270.

${ }^{57}$ Robert D. Putnam, "Bowling Alone: America's Declining Social Capital," Issues of Democracy, 1.8, July 1996, 2-7.

58 James A. Henretta, America’s History (New York: St. Martin’s Press, 2011), 932-933.

${ }^{59}$ U. S. Supreme Court, Lau v. Nichols, 414 U.S. 563 (1974),

${ }^{60}$ Gayle Fisher-Stewart, Preaching Black Lives Matter (New York: Church Publishing, 2020), 178, 274.

${ }^{61}$ Mark Bray, Antifa: The anti-fascist handbook (Melbourne Australia: Melbourne University Press, 2017 ), 210.

${ }^{62}$ Lao-tzu, Tao Te Ching trans. Stephen Mitchell (New York: HarperCollins, 1988), 4, 18.
} 
"white privilege," racism, capitalism, police brutality, the military-industrial complex, the economic deprivation of poor people., and pollution of the planet. Many liberal mayors and governors remained relatively passive as antifa conducted rioting, looting, arson and battery on other citizens with whom they disagree. Examples are Seattle, Chicago, New York City, Kenosha, Portland, Baltimore, and Minneapolis and Washington, D.C. ${ }^{63}$

The United States Republic has been involved in wars since its founding. Military conflicts have periodically raged from the War of 1812 to the Iraq War (2003-2011). Both Roman and American leaders learned that a state that exercised control or compelling influence across wide geographical distances during warfare would never return to its previous form. ${ }^{64}$ The greatest threat to the U.S. Republic stems from Presidential aggrandizement during time of war. This process involves a series of institutional changes impairing the ability of political opposition to check and balance executive orders. Institutional changes, made through legal channels, give the appearance that the presidency has a democratic mandate. During the American Civil War President Abraham Lincoln suspended the writ of habeas corpus and imprisoned 15000 people without trial. ${ }^{65}$ The Roosevelt Corollary to the Monroe Doctrine in 1904 allowed American intervention by U.S. military forces in Cuba, Santo Domingo, Haiti, and Nicaragua. ${ }^{66}$ On 1942 President Franklyn Roosevelt ordered 112,000 Japanese Americans living on the west coast of the United States into internment camps in the American interior. ${ }^{67}$ In 1952 President Harry Truman issued an executive order providing for the seizure and operation of $95 \%$ of America's steel mills. ${ }^{68}$ One-way America could transform into an authoritarian political system is through presidential aggrandizement.

A second way that the United States government could transform into an authoritarian state is through a revolution spawned by Marxists and revolutionary socialists. In this case the Federal government would lose the ability to enforce its laws over a significant part of its territory or population to become a failed state. Varied groups, including the former government, would struggle to establish themselves as the central authority. This struggle could take the form of a civil war, a coup d'état, guerrilla warfare or a combination of these events. The victor would attempt to build a new political, social and economic order. The Russian Revolution of 1917 offers an example. Ultimately, Black Lives Matter and Antifa believe that the current political system is based on the exploitation by privileged Caucasian capitalists of disadvantaged minority groups. From their point of view only violent revolution can lead to a more just system since the privileged white population is not willing to relinquish its political, social and economic dominance by peaceful means. ${ }^{69}$ Lao-tzu points out: "The way to violence can only lead to sorrow." 70

\section{CONCLUSION}

Social capital and virtue are essential to the survival of the United States republic. Military expansion under the concept of manifest destiny has produced an affluent society and superpower status in the world. However, continual undeclared warfare in Korea, Vietnam, the Persian Gulf, Iraq and elsewhere have caused causalities, pain and suffering and added to a growing national debt. The unequal distribution of wealth and social status, combined with a biased criminal justice system based on racism, caused frustration, anger and violent acts by Black Lives Matter and Antifa. Both in ancient Rome and modern America there was conflict between liberals and conservatives "about being burdened by a multitude of people born abroad." ${ }^{\text {"71 }}$ The U.S. republic requires serious reforms

63 Heather Mac Donald, "Four Months of Unprecedented Government Malfeasance," Imprimis, 49.5/6 May June 2020, 1-7.

${ }^{64}$ Edward J. Watts, Mortal Republic: How Rome Fell into Tyranny (New York: Basic Books, 2018), 45.

65 James A. Henretta, America's History (Boston: Bedford/St. Martin’s Press, 2011), 440.

${ }^{66}$ Henretta, America's History, 665-666.

${ }^{67}$ Henrretta, America's History, 771.

${ }^{68}$ David Goldfield, the American Journey (New York: Pearson, 2011), 767-768.

${ }^{69}$ Mark Bray, Antifa: The Anti-Fascist Handbook. (Melbourne, Australia: Melbourne University Press, 2017), 210.

${ }^{70}$ Lao-tzu, Tao Te Ching, 21.

${ }^{71}$ Watts, Mortal Republic: How Rome Fell into Tyranny, 58. 
aimed at equal opportunities and social justice for all Americans. The eminent historian, Edward J. Watts states: "We live in a time of political crisis, when the structures of republics as . . the United States are threatened. ${ }^{72}$ Watts continues: "No republic is eternal. It lives only as long as its citizens want it. And, in both the twenty-first century AD and the first century B.C., when a republic fails to work as intended, its citizens are capable of choosing the stability of autocratic rule over the chaos of a broken republic. ${ }^{73}$ The alternative to a republic for America would likely be a new civil war by revolutionary socialists in the manner of the Soviet experience in 1917. This could give rise to a Marxist dictator or the American ruling class might elect a fascist dictator to quell the disturbances. American citizens would not be happy in either eventuality. When citizens take their republic for granted, that republic is at risk. As Watts correctly states: "In ancient Rome and in the modern world, a republic is a thing to be cherished, protected, and respected. If it fails, an uncertain, dangerous, and destructive future lies on the other side." 74

\section{REFERENCES}

[1] Appian. The Hannibalic War. Vol. I Translated by Horace White. Cambridge: Harvard University Press, 1912.

[2] Appian. The Punic Wars. Vol. I Translated by Horace White. Cambridge: Harvard University Press, 1912.

[3] Bray, Mark. Antifa: The Anti-Fascist Handbook. Melbourne, Australia: Melbourne University Press, 2017.

[4] Broom, Leonard, Sociology. Belmont, CA: Wadsworth, 1990.

[5] Cappon, Lester. The Adams-Jefferson Letters (1819). Chapel Hill: The University of North Carolina Press, 1988.

[6] Dio, Cassius. Roman History. Vol. I Translated by Earnest Cary. Cambridge: Harvard University Press, 1917.

[7] Dupont, Florence. Daily Life in Ancient Rome. Malden: MA: Blackwell, 1997.

[8] Fisher-Stewart, Gayle. Preaching Black Lives Matter. New York: Church Publishing, 2020.

[9] Goldfield, David. The American Journey. New York: Pearson, 2011.

[10] Habicht, Christian. Athens from Alexander to Antony. Cambridge: Harvard University Press, 1997.

[11] Henretta, James. America's History. New York: St. Martin's Press, 2011.

[12] Homer, The Iliad. Translated by Robert Fagles. New York: Penguin Books, 1991.

[13] Josephus, Flavius. The Jewish War. Translated by G.A. Williamson. New York: Penguin Books, 1981.

[14] King, Harold. A History of Civilization New York: Charles Scribner's' Sons, 1969.

[15] Livius, Titus (Livy). History of Rome. Vol. I Translated by B.O. Foster. Cambridge: Harvard University Press, 1924.

[16] Macionis, John. Sociology. New York: Pearson, 2017.

[17] Matyszak, Philip. Chronicle of the Roman Republic. London: Thames \& Hudson, 2003.

[18] MacDonald, Heather. "Four Months of Unprecedented Government Malfeasance." Imprimis 49, no.5/6 (2020): 1-7.

[19] Padover, Saul. A Jefferson Profile as Revealed in his Letters. New York: The John Day Company, 1956.

[20] Plutarch. Plutarch's Lives. Translated by Bernadotte Perrin. London: William Heinemann. 1921.

[21] Polybius. The Histories of Polybius. Translated by W.R. Paton. London: William Heinemann, 1927.

[22] Putnam, Robert. "Bowing Alone: America's Declining Social Capital." Issues of Democracy 1, No. 8 (1996): 2-7.

[23] Sallust, Gaius. The War with Catiline. Translated by J.C. Rolfe. Cambridge: Harvard University Press, 2005.

[24] Spencer, Herbert. Essays: Scientific, Political. and Speculative. Vol. III "The Americans" London: Williams and Norgate, 1891.

[25] Strauss, Barry. The Trojan War. New York: Simon \& Schuster, 2006.

\footnotetext{
${ }^{72}$ Watts, Mortal Republic: How Rome Fell into Tyranny, 7.

${ }^{73}$ Watts, Mortal Republic: How Rome Fell intoTyranny, 8.

${ }^{74}$ Watts, Mortal Republic: How Rome Fell into Tyranny, 281.
} 
[26] Tacitus, Publius. The Annals of Imperial Rome. Translated by Michael Grant. New York: Barnes \& Noble, 1971.

[27] Tranquillus, Gaius Suetonius (Suetonius). The Twelve Caesars. Translated by Robert Graves. New York: Penguin Books, 1989.

[28] Tzu, Lao, Tao Te Ching. Translated by Bryce Derek. New York: Samuel Weiser, 1991.

[29] U.S. Supreme Court, "Lau v. Nichols," 414 U.S. 563 (1974).

[30] U.S. Declaration of Independence. Washington, D.C.: Cato Institute, 2004.

[31] Watts, Edward J. Mortal Republic: How Rome Fell into Tyranny. New York: Basic Books, 2018.

[32] Wills, Gary the Federalist Papers. New York: Bantam Books, 1982.

AUTHORS' BIOGRAPHY

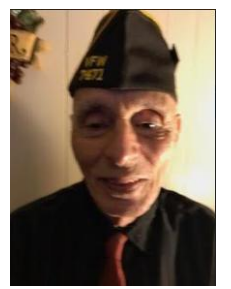

Valentine J. Belfiglio, PhD: Cornaro Professor Emeritus, International Relations and Diplomatic History, Texas Woman's University, Denton, Texas, USA. He published seven books and more than 100 articles in refereed journals and received awards in scholarship from the Texas Woman's University, University of Naples, Italy and the Southeast Texas Historical Association.

Citation: Valentine J. Belfiglio, Ph.D. "Will the United States Republic Become a Dictatorship?" International Journal of Humanities Social Sciences and Education (IJHSSE), vol 7, no. 10, 2020, pp. 78-87. doi: https://doi.org/10.20431/2349-0381.0710010.

Copyright: (C) 2020 Authors. This is an open-access article distributed under the terms of the Creative Commons Attribution License, which permits unrestricted use, distribution, and reproduction in any medium, provided the original author and source are credited. 